10IKC-093

\title{
OXYGEN ISOTOPE STUDIES OF SERPENTINE IN KIMBERLITE
}

\author{
Roger H. Mitchell \\ Department of Geology, Lakehead University, Thunder Bay, Ontario, Canada P7B 5E1
}

\begin{abstract}
Although serpentine is a ubiqu itous mineral kimberlites, its origin remains controversial. Some petrologists claim that all serpen tine is secondary and produced by the introduction of externally-derived fluids, whereas others suggest that serpentine is a primary mineral formed mainly from deuteric fluids. To date the only investigations of the isotopic composition of kimberlite serpentine have been by bulk an alysis of samples that have undergone subaerial alteration, and hence undoubted interaction with meteoric water.
\end{abstract}

As previous studies have failed to resolve the serpentine genetic problem, an investigation of the isotopic composition of oxygen in kimberlite serpentine/chlorite using SIMS was instigated. Serpentine and chlorite in kimberlites occurs as: (1) pseudomorphic retrograde lizardite and chlorite after primary olivine (2) late stage primaryserpophitic serpentine; (3) prograde serpophitic serpentine replacing retrograde lizardite; (4) chlorite replacing interclast phlogopite in diatreme zone rocks. Serpophitic or polygonal serpentine is a primary low temperature phase that commonly forms monomineralic segregations in the groundmass of hypabyssal kimberlites.

In this study the oxygen isotopic composition of all varieties of serpentine were determined in hypabyssal and diatreme facies kimberlites from Southern Africa, Canada and the USA. Data were acquired using the Edinburgh Cameca ims 1270 ion microprobe, using a $\sim 5$ nA primary ${ }^{133} \mathrm{Cs}^{+}$beam, and an antigorite $\left({ }^{18} \mathrm{O}=8.8\right.$ \%) standard.

In Iron Mountain hypabyssal kimberlites the ${ }^{18} \mathrm{O}$ of pseudomorphic marginal and vein serpentine (Fig. 1) is similar and ranges between +4.25 and $+6.25 \%$. For compositionally zoned pseudomorphic marginal serpentines, from Wes selton (Figs. 2-3) ${ }^{18} \mathrm{O}$ decreases from core-to-rim (cores +6.42 to $+3.77 \%$ o ${ }^{18} \mathrm{O}$; rims +2.67 to $\left.+0.57 \%{ }^{18} \mathrm{O}\right)$.
Prograde pseudomorphic serpophite in the Ham West kimberlites (Figs. 4-6) ranges in ${ }^{18} \mathrm{O}$ from +4.14 to $0.50 \%$, with segregationary primary serpophite ${ }^{18} \mathrm{O}$ ranging from +1.60 to $-1.84 \%$.

In diatreme zone rocks at Letseng-la-terae (Figs 7-9), the earliest pseudomorphic serpentine/chlorites range in

${ }^{18} \mathrm{O}$ from +5.03 to $+3.49 \%$, later-forming rim and marginal serpentine/chlorites from +4.34 to $-1.77 \%$, with interclast serpophite from +3.41 to $+1.47 \%$. At Kao, the earliest pseudomorphic serpentine/chlorites are relatively uniform in composition and range in ${ }^{18} \mathrm{O}$ from +4.94 to $+4.50 \%$, later rim and marginal serpentines from +4.92 to $+4.78 \%$, and interclast serpophite from +6.25 to $+3.80 \%$.

These data show that the kimberlites investigated have not interacted with large volumes of light meteoric waters. Similar oxygen isotopic compositions in hypabyssal and diatreme zones rocks from different localities certainly preclude introduction of meteoritic water. The tren ds from man tle oxygen to lighter oxygen are a result of either fluid compositional evolution or very minor introduction of light water.

Assuming that parental olivine has a primary ${ }^{18} \mathrm{O}$ of about $+6 \%$, and that this is reduced during serpentinization by ${ }^{16} \mathrm{O}$ enrichment caused by reactions with isotopically lighter water (-10 to - $20 \%$ ), at 200 $300^{\circ} \mathrm{C}$, in closed or open systems, then "water/serp entine" ratios can not exceed 0.8 at.\%. These data are interpreted to suggest that there was not an influx of significant volumes of low temperature meteoric water as a cause of serpentinization. This conclu sion is supported by theabsence of extremelylight oxygen (i.e. ${ }^{18} \mathrm{O}<-5 \%$ ) in all of the serpentines investigated. 
Figure 1. Retrograde pseudomorphic serpentine replacing olivine macrocrysts in the Iron Mountain hypabyssal kimberlite. Numbers indicate analytical points.

Figure 2. Retrograde pseudomorphic serpentine replacing primary olivine microphenocrysts in Wesselton W7 hypabyssal kimberlite. Numbers are analytical points

Figure 3. Core-to-rim variations in the isotopic composition of oxygen versus total $\mathrm{FeO}$ content of serpentine replacing an olivine microphenocryst in Wesselton W7 hypabyssal kimber lite. Note that very light oxygen is not present and that the core of the crystal contains oxygen with mantle oxygen compositions. Serpentines decrease in $\mathrm{FeO}_{\mathrm{T}}$ from core to rim of the pseudomorph.
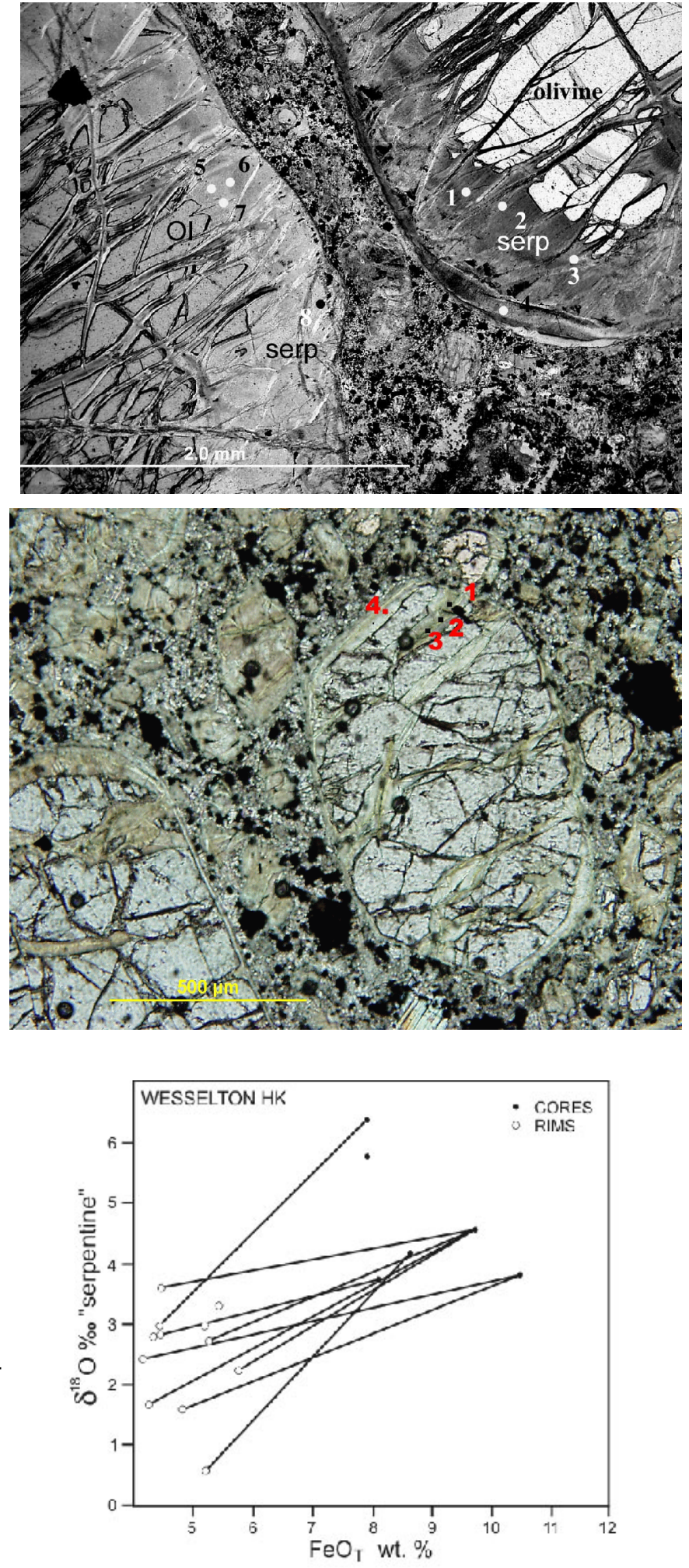
Figure 4 . Serpophitic segregationary serpentine (S) in the Ham West hypabyssal kimberlite, Somerset Island Canada.

This is a typical example of late-stage primary Povlen-type serpentine.

TEM and Raman spectrometry shows this

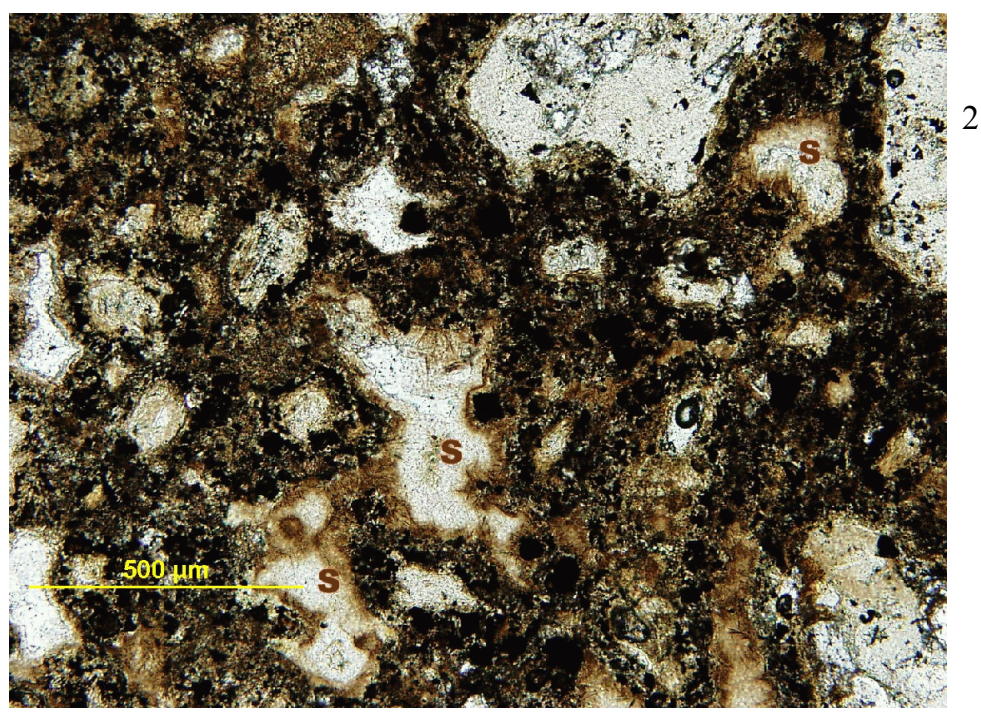
to be composed of nanometer size plates of lizardite

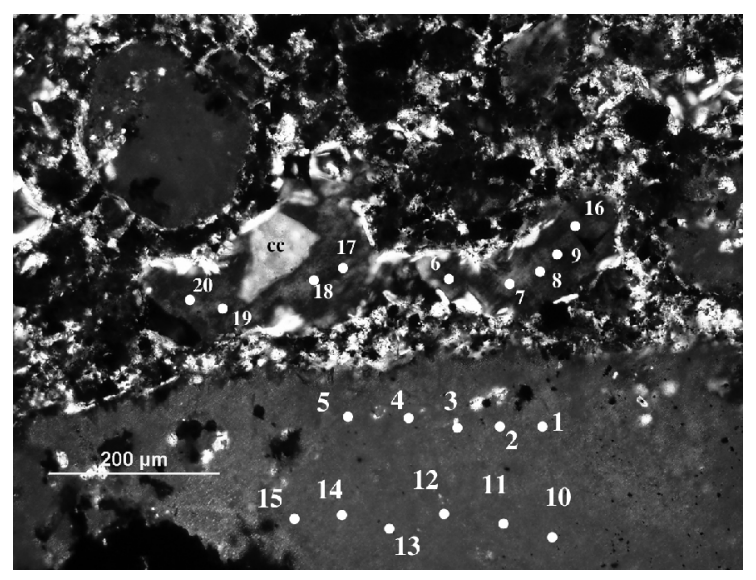

Figure 5

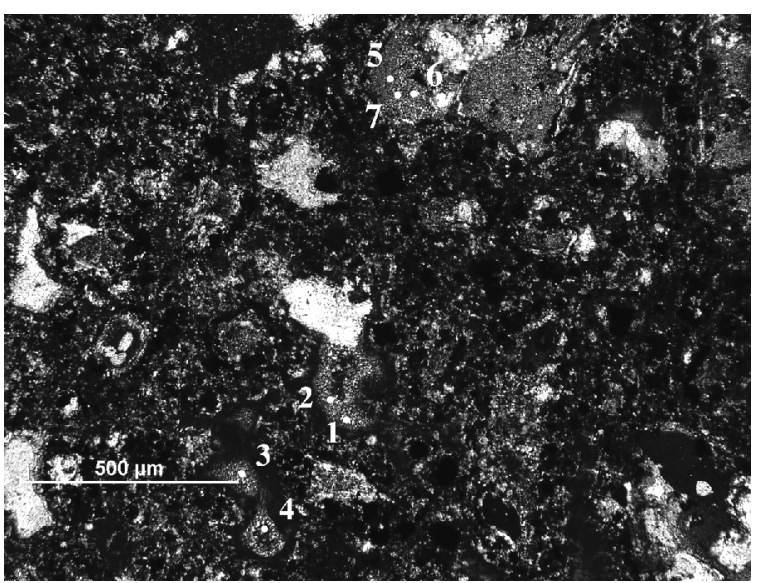

Figure 6

Figures 5 and 6 are crossed polarized light photomicrographs of near-isotropic primary serpophitic serpentine in the Ham West hypabyssal kimberlite. Numbers are analytical points. This segregationary primary serpophite has ${ }^{18} \mathrm{O}$ ranging from +1.60 to $-1.84 \%$. 
Figure 7 . Tuffisitic kimberlite from Letseng-la-terae, Lesotho.

The sample consists of chlor ite pseudomorphs after macrocrystal olivine set in a chlorite-diopside interclast matrix.

Numbers are analytical points .

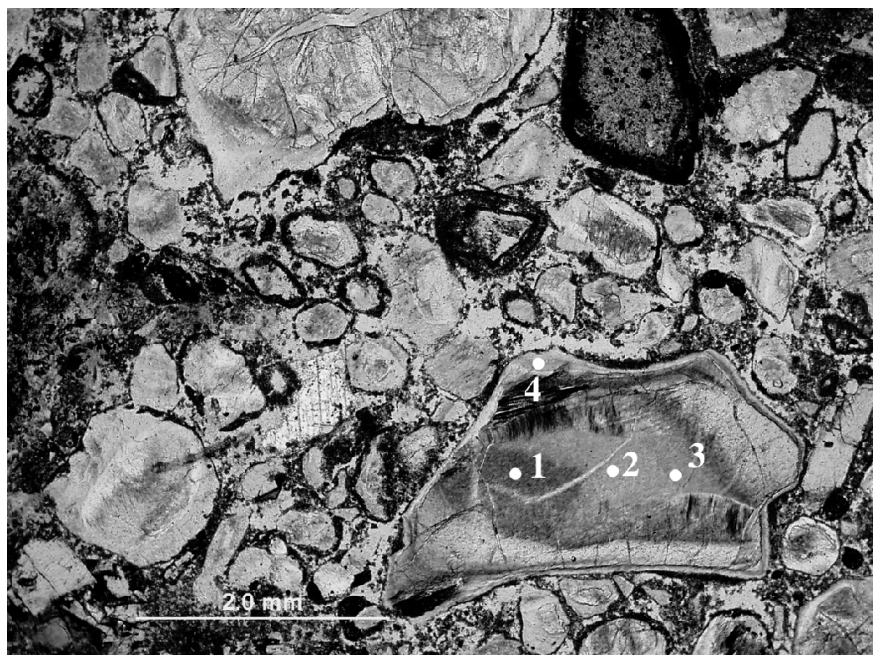

Figure 8. Tuffisitic kimberlite from Letseng-la-terae, Lesotho.

The sample consists of chlorite pseudomorphs after macrocrystal olivine set in a chlorite-diopside interclast matrix.

Numbers are analytical points .

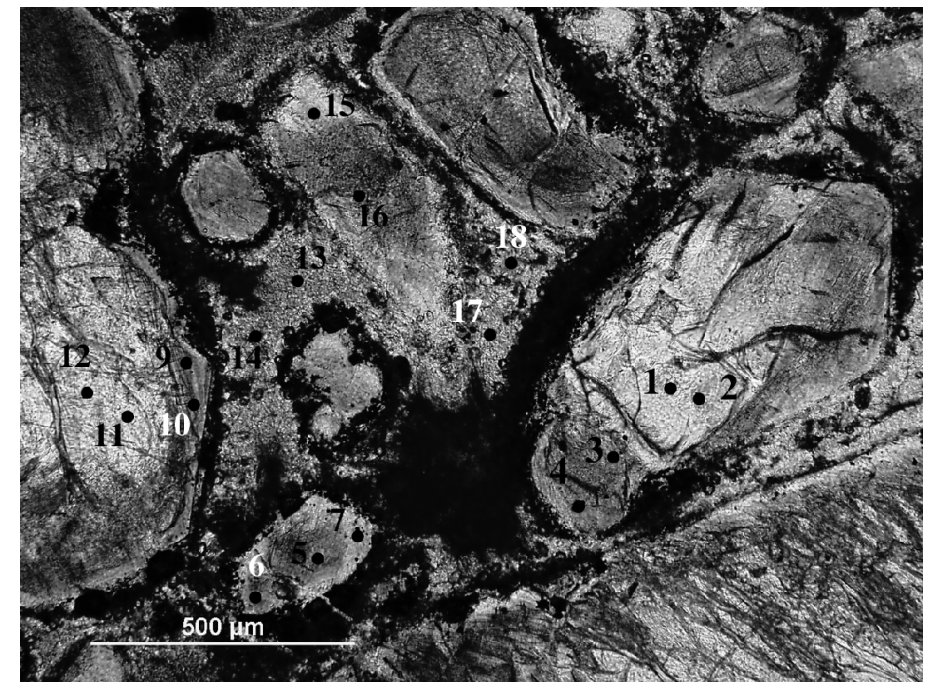

Figure 9 Cor e-to-rime var iations in the isotopic composition of oxygen versus total iron content of olivine macrocrysts replaced by pseudomorphic chlorite in tuffisitic kimberlite from Letseng-la-terae, Lesotho.

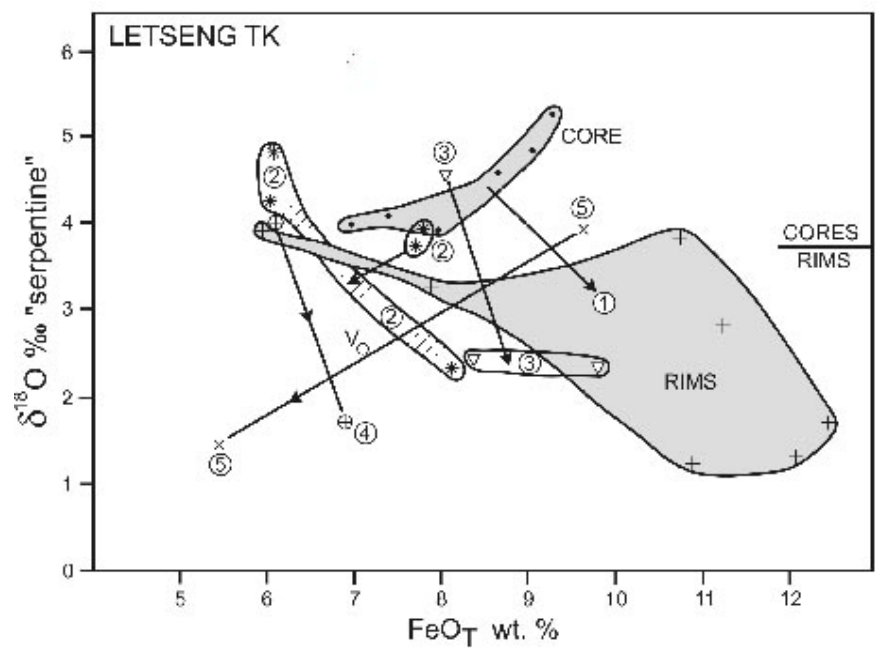


Figure 10

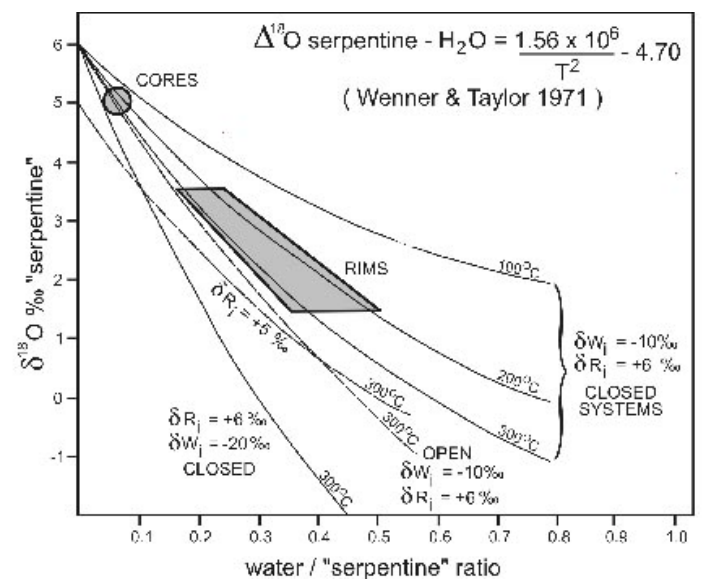

Figure 10 shows how the oxygen isotopic compositions of pseudomorphic serpentine might change as a function of water/serpentine ratios in open and closed systems. It is assumed that parental olivine has a primary ${ }^{18} \mathrm{O}$ of about $+6 \%$, i.e. similar to that of fresh olivine in kimberlite and ultramafic rocks, and that this is reduced by ${ }^{16} \mathrm{O}$ enrichment due to reactions with isotopically lighter water. Figure 10 indicates that for serpentinization at $200-300^{\circ} \mathrm{C}$ in closed systems with initial water compositions ranging from -10 to $-20 \%$, that "water/serpentine" ratios cannot exceed 0.8 at.\%. Low temperature $\left(<100^{\circ} \mathrm{C}\right)$ serpentinization is considered to be an unlikely process with respect to the probable serpentinization temperatures of kimberlites $\left(200-400^{\circ} \mathrm{C}\right)$, and effectively rules out high $(>1$ at.\%) "water/serpentine" ratios as a cause for the isotopic trends observed. Thus, these data are interpreted to suggest that there was not an influx of significant volumes of low temperature meteoric water as a cause of serpentinization. This conclusion is supported by the absence of extremely light oxygen (i.e. ${ }^{18} \mathrm{O}<-5 \%$ ) in all of the serpentines occurring in the kimberlites investigated. Similar conclusions can be drawn for open systems (Fig. 10).

The calcul ated low water/serpentine ratios and ${ }^{16} \mathrm{O}$ enrichment trends, in themselves do not rule out some limited influx of meteoric water, although they clearly demonstrate that this is not a volumetrically important process in the formation of serpentine in kimberlite. However, this observation does not imply that such a secondary process is the primary cause of serpentinization. This is because petrographic observations together with $\mathrm{O}$ and $\mathrm{C}$ isotopic data for associated carbonates $h$ ave provided conclu sive evidence that serpophit e-carbonate segregation s in kim berlites are of deuteric origin and not post-emplacement secondary replacement features. Such processes cannot producethe complex textural and paragenetic relationships actually observed, and would result in pervasive uniform serpentinization with or without secondary calcite. It is unreasonable to expect that post-emplacement secondary serpentinization would producesimilar petrographic and mineralogical features in kimber lites of diverse age and emplacement conditions in different groundwater regimes. Consequently, it is concluded here that the water involved in vein and marginal serpentinization and formation of serpophite-calcite segregations is also principally of deuteric origin. On the basis of petrographic criteria the serpentine-chlorite of the interclast matrices of tuffisitic kimber lites is consi dered to result from the alteration of pre-existing phyllosilicates (phlogopite) by deuteric fluids. These fluids on the basis of the $\mathrm{O}$ isotopic data presented here are considered also to be of deuteric origin. However, fluids which resulted in the marginal and pseudomorphic serpentinization of olivine in magmaclasts may (e.g. Letseng-la-terae) or may not (e.g. Kao) be the same as those forming the interclast matrix serpentine chlorite. 